\title{
A comparative analysis of caries and fluorosis among cities with and without public water supply fluoridation in São Paulo State, Brazil
}

\author{
Análise comparativa de cárie e fluorose entre municípios paulistas \\ com e sem fluoretação das águas de abastecimento público
}

\begin{abstract}
Purpose: This population-based, cross-sectional study aimed to record the DMFT index for 12 year-old children with dental caries and fluorosis levels in cities with and without public water supply fluoridation.

Methods: From the 101 municipalities belonging to the Health Regional Department XV (DRSXV-SJRP) of the São Paulo state in the Southeast region of Brazil, 85 cities were selected after exclusion of those with incomplete data and less than ten years of fluoridation treatment in 2004. The criteria adopted for the assessment of dental caries and fluorosis levels were based on the guidelines published in the WHO Manual 4th edition. The data were analyzed using Fisher's exact tests at a significance level of 5\%.

Results: The prevalence of caries in 12 year-old children had no significant association with fluoridated water, and was considered "moderate" and "high" in cities without fluoridation and "low" and "moderate" in cities with fluoridation. A significant association was found between water fluoridation and fluorosis $(P=0.001)$, but not between water fluoridation and the DMFT index $(P=0.119)$.

Conclusion: The prevalence of fluorosis was related to water fluoridation in this study. However, fluorosis was also observed in non-fluoridated cities, which may result from fluoride intake through other sources.
\end{abstract}

Key words: Dental caries; fluorosis, dental; fluoridation

\section{Resumo}

Objetivo: Este estudo transversal, de base populacional, teve por objetivo medir os índices CPO-D aos 12 anos e de fluorose em municípios com e sem fluoretação da água de abastecimento público.

Metodologia: De 101 municípios pertencentes à Divisão Regional de Saúde XV - São José do Rio Preto (DRS-XV), Estado de São Paulo, na região Sudeste do Brasil, foram selecionados 85 municípios, sendo excluídos os aqueles que apresentaram dados incompletos e que possuíam menos de dez anos de fluoretação em 2004. Os critérios adotados para avaliação de cárie e fluorose foram baseados no manual da OMS $4^{a}$ edição. Os dados foram submetidos à análise estatística através do teste Exato de Fisher, ao nível de significância 5\%.

Resultados: A prevalência de cárie aos 12 anos não teve associação significativa com a água fluoretada e foi considerada "moderada" e "alta" em municípios sem fluoretação e "baixa" e "moderada" nos municípios com fluoretação. A água fluoretada teve associação significativa com fluorose $(P=0,001)$ mas não com o índice CPO-D $(P=0,119)$.

Conclusão: Houve associação entre prevalência de fluorose e água fluoretada, mas a fluorose também foi observada em municípios sem fluoretação, possivelmente pelo flúor existente nas diversas fontes de ingestão.

Palavras-chave: Cárie dentária; fluorose dentária; fluoretação

\author{
Suzely Adas Saliba Moimaz a \\ Adriana Cristina Oliva Costa ${ }^{b}$ \\ Lígia Prandi da Silva ${ }^{b}$ \\ Orlando Saliba ${ }^{a}$ \\ Cléa Adas Saliba Garbina \\ Kátia Santos Araújoc
}

\begin{abstract}
a Department of Pediatric and Social Dentistry, Araçatuba Dental School, Paulista State University (UNESP), Araçatuba, SP, Brazil

b Araçatuba Dental School, Paulista State University (UNESP), Araçatuba, SP, Brazil

c Health Regional Department XV of São José do Rio Preto, São José do Rio Preto, SP, Brazil
\end{abstract}




\section{Introduction}

The prevention of dental caries can be achieved by many methods, such as fluoridation of the public water supply. This universal and effective method has received considerable attention since the inception of the Smiling Brazil Program by the Federal Government on March 17 $7^{\text {th }}, 2004$. This program aims to treat and improve the general oral health of the Brazilian population. Fluoridation of the public water supply is recommended by many scientific and health organizations worldwide, such as the World Dental Federation (FDI), the International Association for Dental Research (IADR), the World Health Organization (WHO), and the Pan American Health Organization (PAHO) (1).

Water fluoridation is an administrative action with a high efficiency, a relatively low cost, and a large social benefit, which has been shown to improve the overall quality of life for individuals and populations. If the per capta social cost is economically viable, water fluoridation may significantly transform the epidemiological profile of dental caries incidence, and decrease the social inequality for access to products with fluoride content that can benefit all social classes in the population (2).

In Brazil, this preventive method was introduced in 1953 with the fluoridation of the public water supply of Baixo Gandu city in Espírito Santo state (Southeast region of Brazil). After this implementation, the local governments of several states and cities around the country discussed the adoption of this measure (3). The Brazilian National Congress approved Law 6050 on May 24 $4^{\text {th }}, 1974$, which was later regulated by Federal Decree 76.872 from the Republic Presidency (March 22 $2^{\text {th }}, 1975$ ) and Government Decree 635 from the Health Ministry (December, 1975), to become the legal instrument for obligatory public water fluoridation in Brazil (4). The implementation of this measure in the country accelerated during the second half of the 1970s due to funding that financed the implantation, amplification, and improvement of water supply systems that contributed to the expansion of fluoridation in 1983 (5). The efficiency and security of public water fluoridation supply depends on the maintenance of optimal fluoride concentrations, which requires alert systems to monitor water fluoridation (6). The cities that do not follow the recommended standards for water fluoridation may place populations at higher risk for caries when the fluoride level is low, and dental fluorosis when the fluoride level is high $(7,8)$.

Both WHO and FDI recommended a DMFT index lower than or equal to 3 for 12-year-old children in 2000 and lower than 1 in 2010 (9). A decrease in dental caries after implementation of water fluoridation has been shown in São Paulo state. The survey of São Paulo State Population Oral Health Conditions in 1998 demonstrated that the average DFMT for 12 year-old children declined from 6.47 in 1986 to 3.72 in 1998 and 2.5 in 2002. Epidemiological surveys in Brazil have shown a decrease in dental caries and an increase in dental fluorosis (10), particularly fluorosis at light and very light levels $(11,12)$. The manifestations associated with dental fluorosis are related to the exposure of the tooth germ to high fluoride ion concentrations during the tooth formation period (13). Uchôa and Saliba (14) published the first report from São Paulo state on endemic fluorosis in students of Pereira Barreto city that were exposed to the public water supply from three sources of well-water with fluoride levels ranging from 2.5 to $17.5 \mathrm{ppmF}$.

Considering the importance of water fluoridation as a preventive strategy for the prevelance of public caries, this cross-sectional, population-based study aimed to record the DMFT index for 12 year-old children with dental caries and fluorosis levels in cities with and without public water fluoridation supply.

\section{Methodology}

This study used the database of the 2004 Resolution annexed IV and V, Health Regional Department XV (DRS-XV-SJRP) of the São Paulo state in the Southeast region of Brazil. This database contains information from 2004 on the cities that did not have public water fluoridation supply, cities with water fluoridation for over 10 years, the DMFT index for 12 year-old children, and fluorosis occurrence and levels. From the 101 municipalities belonging to the Health Regional Department XV (DRS-XV-SJRP) of the São Paulo state, 85 cities were selected after exclusion of those with incomplete data and less than 10 years of fluoridation in 2004. The criteria adopted for the assessment of dental caries and fluorosis, were based on the guidelines published in the WHO Manual 4th edition. According to the WHO categories for caries prevalence, the cities were classified in the following groups: very low, low, moderate, high, and very high. To record fluorosis occurrence, the following levels were considered: normal, questionable, very light, light, moderate, and severe. Normal and questionable levels of fluorosis were similar to the levels found in children without fluorosis.

The data were statistically analyzed using Fisher's Exact Test at the significance level of 5\%.

\section{Results}

The Health Regional Department DRS XV of São José do Rio Preto City, interior of São Paulo State, had 101 cities in 2004, but the final sample of this study was 85 cities. From these 85 cities, only 33 (39\%) had water fluoridation for over 10 years.

According to the WHO classification of caries prevalence in 12 year-old children, no city was categorized as "very high". Among the 33 cities with water fluoridation, $6 \%$ were classified as "very low" for the prevalence of dental caries; $61 \%$ as "low"; $30 \%$ as "moderate" and $3 \%$ as "high". Among the 52 cities without water fluoridation, $11.5 \%$ were classified as "very low"; $36.5 \%$ as "low"; $40.4 \%$ as "moderate" and $11.5 \%$ as "high" (Table 1). Although no significant difference was found for DMFT between cities with and without water fluoridation $(P=0.119)$, the cities without water fluoridation showed a "moderate" (40.4\%) 
and a "high" (11.5\%) prevalence of dental caries in 12 yearold children. These percentages are greater than those found in cities with water fluoridation $(30 \%$ as "moderate" and $3 \%$ as "high") (Table 1).

Table 2 shows the results for fluorosis in cities with and without water fluoridation over ten years. From the 33 cities with water fluoridation, 30\% (10) did not show dental fluorosis and 70\% (23) exhibited fluorosis levels that were predominantly "very light" and "light" (Table 3). Among the 52 cities without water fluoridation, 69\% (36) were free of fluorosis and $31 \%$ (16) exhibited intra-variation of fluorosis levels (Table 4).
Table 1. Distribution of the evaluated cities according to the prevalence of dental caries at the age of 12 years-old. Health Regional Department XV - São José do Rio Preto, São Paulo state, 2004.

\begin{tabular}{lcccccc}
\hline \multicolumn{1}{c}{$\begin{array}{c}\text { DMFT } \\
\text { (12 years-old) }\end{array}$} & \multicolumn{2}{c}{ With fluoride } & Without fluoride & \multicolumn{2}{c}{ Total } \\
\cline { 2 - 7 } & $\mathbf{n}$ & $\%$ & $\mathbf{n}$ & $\%$ & $\mathbf{n}$ & $\%$ \\
\hline Very low $(0.0-1.1)$ & 2 & 6 & 6 & 11.5 & 8 & 9.4 \\
Low $(1.2-2.6)$ & 20 & 61 & 19 & 36.5 & 39 & 46 \\
Moderate $(2.7-4.4)$ & 10 & 30 & 21 & 40.4 & 31 & 36.4 \\
High (4.5-6.5) & 1 & 3 & 6 & 11.5 & 7 & 8.2 \\
Very high (more than 6.5) & 0 & 0 & 0 & 0 & 0 & 0 \\
Total & 33 & 100 & 52 & 100 & 85 & 100 \\
\hline
\end{tabular}

* $P=0.119$
Table 2. Frequency of dental fluorosis in the cities evaluated. Health Regional Department XV - São José do Rio Preto, São Paulo state, 2004.

\begin{tabular}{lcccccc}
\hline \multirow{2}{*}{ Cities } & \multicolumn{2}{c}{ Fluorosis } & \multicolumn{2}{c}{ No Fluorosis } & \multicolumn{2}{c}{ Total } \\
\cline { 2 - 7 } & $\mathbf{n}$ & $\%$ & $\mathbf{n}$ & $\%$ & $\mathbf{n}$ & $\%$ \\
\hline With fluoride & 23 & 70 & 10 & 30 & 33 & 39 \\
Without fluoride & 16 & 31 & 36 & 69 & 52 & 61 \\
Total & 39 & 46 & 46 & 54 & 85 & 100 \\
\hline
\end{tabular}

$* P=0.001$

Table 3. Distribution of the dental fluorosis levels in the cities with fluoridation of the public water supply. Health Regional Department DRS XV, São Paulo state, 2004.

\begin{tabular}{|c|c|c|c|c|c|c|c|}
\hline \multirow{2}{*}{ City } & \multirow{2}{*}{$\begin{array}{c}\text { Water Fluoridation } \\
\text { (years) }\end{array}$} & \multicolumn{6}{|c|}{ Dental fluorosis in 12 year-old children } \\
\hline & & Normal & Questionable & Very Light & Light & Moderate & Severe \\
\hline Adolfo & 19 & $90 \%$ & $0 \%$ & $4 \%$ & $3 \%$ & $3 \%$ & $0 \%$ \\
\hline Álvares Florence & 13 & $68 \%$ & $6 \%$ & $12 \%$ & $11 \%$ & $0 \%$ & $0 \%$ \\
\hline Dirce Reis & 22 & $73 \%$ & $17 \%$ & $6 \%$ & $3 \%$ & $0 \%$ & $0 \%$ \\
\hline Estrela D'oeste & 15 & $80 \%$ & $14 \%$ & $3 \%$ & $3 \%$ & $0 \%$ & $0 \%$ \\
\hline Floreal & 15 & $95 \%$ & $0 \%$ & $5 \%$ & $0 \%$ & $0 \%$ & $0 \%$ \\
\hline Icem & 20 & $87 \%$ & $11 \%$ & $2 \%$ & $0 \%$ & $0 \%$ & $0 \%$ \\
\hline Irapuã & 24 & $85 \%$ & $2 \%$ & $9 \%$ & $3 \%$ & $1 \%$ & $0 \%$ \\
\hline Jales & 19 & $81 \%$ & $12 \%$ & $5 \%$ & $2 \%$ & $0 \%$ & $0 \%$ \\
\hline Novo Horizonte & 11 & $63 \%$ & $14 \%$ & $12 \%$ & $9 \%$ & $2 \%$ & $0 \%$ \\
\hline Onda Verde & 16 & $30 \%$ & $0 \%$ & $4 \%$ & $33 \%$ & $23 \%$ & $10 \%$ \\
\hline Ouroeste & 16 & $86 \%$ & $2 \%$ & $8 \%$ & $4 \%$ & $0 \%$ & $0 \%$ \\
\hline Palmares Paulista & 21 & $67 \%$ & $27 \%$ & $6 \%$ & $0 \%$ & $0 \%$ & $0 \%$ \\
\hline Palmeira D'oeste & 15 & $90 \%$ & $7 \%$ & $0 \%$ & $0 \%$ & $3 \%$ & $0 \%$ \\
\hline Parisi & 18 & $79 \%$ & $4 \%$ & $9 \%$ & $4 \%$ & $4 \%$ & $0 \%$ \\
\hline Poloni & 21 & $87 \%$ & $7 \%$ & $3 \%$ & $3 \%$ & $0 \%$ & $0 \%$ \\
\hline Pontes Gestal & 20 & $93 \%$ & $0 \%$ & $5 \%$ & $2 \%$ & $0 \%$ & $0 \%$ \\
\hline Populina & 21 & $90 \%$ & $3 \%$ & $7 \%$ & $0 \%$ & $0 \%$ & $0 \%$ \\
\hline Riolândia & 18 & $75 \%$ & $13 \%$ & $5 \%$ & $7 \%$ & $0 \%$ & $0 \%$ \\
\hline Santa Salete & 13 & $97 \%$ & $0 \%$ & $3 \%$ & $0 \%$ & $0 \%$ & $0 \%$ \\
\hline São Francisco & 21 & $95 \%$ & $2 \%$ & $3 \%$ & $0 \%$ & $0 \%$ & $0 \%$ \\
\hline Urânia & 19 & $95 \%$ & $2 \%$ & $1 \%$ & $1 \%$ & $1 \%$ & $0 \%$ \\
\hline Valentim Gentil & 21 & $92 \%$ & $6 \%$ & $2 \%$ & $0 \%$ & $0 \%$ & $0 \%$ \\
\hline Zacarias & 18 & $92 \%$ & $4 \%$ & $0 \%$ & $0 \%$ & $0 \%$ & $4 \%$ \\
\hline
\end{tabular}

Source: Health Regional Department DRS XV São José do Rio Preto City, São Paulo state, Brazil, 2008. Resolution-Anexxed V 
Table 4. Distribution of the levels of dental fluorosis in the cities without fluoridation of the public water supply. Health Regional Department XV - São José do Rio Preto, São Paulo state, 2004.

\begin{tabular}{|c|c|c|c|c|c|c|c|}
\hline \multirow{2}{*}{ City } & \multirow{2}{*}{$\begin{array}{l}\text { Water Fluoridation } \\
\text { (years) }\end{array}$} & \multicolumn{6}{|c|}{ Dental fluorosis in 12 year-old children } \\
\hline & & Normal & Questionable & Very light & Light & Moderate & Severe \\
\hline Ariranha & 0 & $85 \%$ & $10 \%$ & $5 \%$ & $0 \%$ & $0 \%$ & $0 \%$ \\
\hline Aspásia & 0 & $93 \%$ & $0 \%$ & $0 \%$ & $0 \%$ & $7 \%$ & $0 \%$ \\
\hline José Bonifácio & 0 & $90 \%$ & $0 \%$ & $7 \%$ & $3 \%$ & $0 \%$ & $0 \%$ \\
\hline Marinopolis & 0 & $90 \%$ & $0 \%$ & $0 \%$ & $10 \%$ & $0 \%$ & $0 \%$ \\
\hline Merediano & 0 & $90 \%$ & $7 \%$ & $3 \%$ & $0 \%$ & $0 \%$ & $0 \%$ \\
\hline Mira Estrela & 0 & $27 \%$ & $27 \%$ & $30 \%$ & $13 \%$ & $0 \%$ & $3 \%$ \\
\hline Mirassol & 0 & $92 \%$ & $3 \%$ & $2 \%$ & $2 \%$ & $1 \%$ & $0 \%$ \\
\hline Nhandeara & 0 & $97 \%$ & $0 \%$ & $3 \%$ & $0 \%$ & $0 \%$ & $0 \%$ \\
\hline Paulista & 0 & $78 \%$ & $9 \%$ & $13 \%$ & $0 \%$ & $0 \%$ & $0 \%$ \\
\hline Pedranopolis & 0 & $70 \%$ & $10 \%$ & $7 \%$ & $7 \%$ & $6 \%$ & $0 \%$ \\
\hline Pontalinda & 0 & $73 \%$ & $10 \%$ & $17 \%$ & $0 \%$ & $0 \%$ & $0 \%$ \\
\hline Rubineia & 0 & $86 \%$ & $8 \%$ & $6 \%$ & $0 \%$ & $0 \%$ & $0 \%$ \\
\hline Santa Fé do Sul & 0 & $80 \%$ & $13 \%$ & $5 \%$ & $2 \%$ & $0 \%$ & $0 \%$ \\
\hline Santa Rita D'Oeste & 0 & $90 \%$ & $0 \%$ & $10 \%$ & $0 \%$ & $0 \%$ & $0 \%$ \\
\hline Urupês & 0 & $97 \%$ & $1 \%$ & $0 \%$ & $2 \%$ & $0 \%$ & $0 \%$ \\
\hline Votuporanga & 0 & $88 \%$ & $1 \%$ & $8 \%$ & $2 \%$ & $1 \%$ & $0 \%$ \\
\hline
\end{tabular}

Source: Health Regional Department DRS XV São José do Rio Preto City, São Paulo state, Brazil, 2008. Resolution-Anexxed V.

\section{Discussion}

The decline in the prevalence of dental caries in Brazil can be related to the implementation of national basic health programs, such as the fluoridation of the public water supply. Although water fluoridation in Brazil has accelerated since 1975, the present study demonstrated that the public health policy of water fluoridation was not very effective in reducing the incidence of dental caries in most cities of the DRS-XV in 2004. The existence of such legislation for obligatory water fluoridation in Brazil (Law 6050/1975) and the availability of funding sources as well as scientific evidence did not persuade city governors to adopt this preventive method in this region of São Paulo State. The lack of fluoride in the water supply may be a determinant of the high DMFT index of several cities without fluoridation, but the low adherence to this public policy was not an exclusive characteristic of this DRS-XV. According to the Brazilian Health Ministry (1), only $40 \%$ of the Brazilian population had access to fluoridated water in 2004.

Therefore, other aspects of this process must be considered in addition to the legislation of water fluoridation and monitoring power, such as the following: technical assistance for the cities, especially those with difficulties elaborating a public project for adequate water fluoridation; training the operators of the public water supply system regarding the technical features of water fluoridation, and the distribution of the municipal budget according to the needs of the water supply system of each city. Those measures would strengthen the continuing process of water fluoridation in the cities and benefit the entire population. According to Fernandes et al., water fluoridation has therapeutic qualities, and is a population-based strategy to promote the reduction of social inequalities among the different socioeconomic strata (15).

The decrease in the DMFT index is related to ingestion of adequate daily doses of fluoride. Although no significant difference in the DMFT index was observed between cities with and without water fluoridation in the present study, previous investigations $(11,16,17)$ have demonstrated the effectiveness of water fluoridation in reducing dental caries in 12 year-old children. Some limitations of the present findings are due to the secondary characteristics of the database, since some of the information was not accurate in terms of "use of fluoride". In a general perspective, other methods of fluoride use in current practice were not accounted for in the cities evaluated.

Fluorosis was observed in cities with and without public water fluoridation supply, which is most likely the result of alternative mechanisms of fluoride ingestion during the tooth formation period. The most prevalent fluorosis levels in the present study were "very light" and "light", which corroborated previous reports (11-13). Fluorosis occurred in cities without water fluoridation, which suggest exposure to others sources of fluoride, such as dentifrices, mouth rinses, and polivitamins (12). A lack of knowledge regarding these alternative fluoride sources and the adverse effects of fluoride due to excessive ingestion were shown to be important factors in the occurrence of fluorosis. Martins et al. (18) reported the significant lack of information on the proper use of fluoride by the population, which is influenced by the false belief that swallowing fluoride is beneficial for children, and that a large amount of fluoridated dentifrice should be used daily. Those authors indicated that the media, and companies that market dentifrice, contribute to the dissemination of incorrect information on the use of fluoridated products. 


\section{Conclusions}

The incidence of dental caries in 12 year-old children was not associated with fluoridation of the public water supply, as "moderate" and "high" prevalence of this condition was observed in cities without water fluoridation, and "low" and "moderate" prevalence of dental caries was observed in cities with fluoridation. Water fluoridation was associated with fluorosis prevalence. However, fluorosis was also detected in cities without fluoridation, which is possibly due to the ingestion of fluoride from sources other than the public water system.

\section{References}

1. Brasil. Ministério da Saúde. Secretaria de Atenção à Saúde. Departamento de Atenção Básica. A fluoretação das águas de abastecimento público como uma medida de garantia ao acesso a água tratada. Rev Bras Saúde Fam 2006;7:4-8.

2. Frias AC, Narvai PC, Araujo ME, Zilbovicius C, Antunes JLF. Custo da fluoretação das águas de abastecimento público, estudo de caso Município de São Paulo, Brasil, período de 1985-2003. Cad Saúde Pública 2006;22:1237-46.

3. Pinto VG. Saúde bucal: odontologia social e preventiva. 2.ed. São Paulo: Santos; 1990.

4. Vianna RBC Coord. Fluoretação da água: como fazer a vigilância sanitária? Rio de Janeiro: Cedros; 1992.

5. Calvo MCM. Situação da fluoretação de águas de abastecimento público no estado de São Paulo [thesis]. São Paulo: Faculdade Saúde Pública, Universidade de São Paulo; 1996.

6. Silva FSJFB, Moimaz SAS, Garbin CAS, Saliba NA, Werner CWA. Heterocontrole do teor de flúor na água de abastecimento público do município de Lins/SP. Rev Fac Odontol Lins 2004; 16:22-8.

7. Buzalaf MA, Granjeiro JM, Damante CA, Ornelas F. Fluctuations in public water fluoride level in Bauru, Brazil. J Public Health Dent 2002;62:173-6.

8. Narvai PC. Cárie dentária e flúor: uma relação do século XX. Ciênc Saúde Coletiva 2000;5:381-92.

9. Secretaria de Estado da Saúde de São Paulo, Núcleo de Estudos e Pesquisas de Sistemas de Saúde, Faculdade de Saúde Pública, Universidade de São Paulo. Condições de saúde bucal no estado de São Paulo em 2002: relatório final. São Paulo: Faculdade de Saúde Pública, Universidade de São Paulo; 2004.
10. Pereira AC, Mialhe FL, Bianchini FLC, Meneghim MC. Prevalência de cárie e fluorose dentária em escolares de cidades com diferentes concentrações de flúor na água de abastecimento. Rev Bras Odontol Saúde Coletiva $2001 ; 2: 34-9$.

11. Cypriano S, Sousa MLR, Rihs LB, Wada RS. Prevalência e severidade da fluorose dentária em Piracicaba, SP, Brasil. RPG Rev Pós-Grad 2004;1 1:67-73.

12. Brandão IMG, Peres AS, Saliba NA, Moimaz SAS. Prevalência de fluorose dentária em escolares de Marinópolis, São Paulo. Cad Saúde Pública 2002;18:877-81.

13. Cangussu MCT, Narvai PC, Castellanos Fernandez R, Diehizian V. A fluorose dentária no Brasil: uma revisão crítica. Cad Saúde Pública 2002;18:7-15.

14. Uchôa HW, Saliba NA. Prevalência de fluorose dental na cidade de Pereira Barreto. Bol Serv Odontol Sanit 1970;6:11-6.

15. Fernandes Junior HM, Antunes LEG, Dockhorn, DMC, Franco FC. Levantamento epidemiológico de cárie dentária no município de Morrinhos do Sul (RS) e avaliação dos níveis de flúor nas fontes de água natural. Rev Odonto Ciênc 2005;20:222-30.

16. Freitag FS, Nummer FV. Prevalência de cárie dentária em escolares de 12 anos de idade em 2002 e 2007 em Lajeado, RS. Bol Saúde 2008;21:65-75.

17. Tiano AV, Moimaz SA, Saliba O, Saliba NA. Dental caries prevalence in children up to 36 months of age attending daycare centers in municipalities with different water fluoride content. J Appl Oral Sci 2009; 17:39-44.

18. Martins CC, Bonanato KT, Valério DS, Moura Leite FR, Paiva SM, Vale MPP. Efetividade de uma técnica educativa na aquisição de conhecimentos por pais sobre o uso racional do flúor. Rev Odonto Ciênc 2006;21:105-11. 